\title{
電車, 客車の螢光放電燈の照明の展望
}

\section{正会員星 隼 $0^{*}$ 正会員 鈴木 丑 水* 正会員 朝 野 通**}

\section{1. 客車照明に螢光燈の採用}

（1）直流による点燈 わが国の電車には 今ま で交流電源をもったものが全くなく, 制御用電源の電動 発電機-直流 $100 \mathrm{~V}$ で点登したのが最初である.

a. 昭和 21 年 9 月 国電横浜線の 1 両に $\mathrm{FL}-20 \mathrm{D}$ を点登した。

b. 昭和 22 年度 国電新造ジュラルミン車 6 両に $\mathrm{FL}$ $-20 \mathrm{D}$ (内 1 両 $\mathrm{FL}-17 \mathrm{D}$ ) を採用し，京浜東北線に配 属された。

c. 昭和 23 年度 国電モハ 63 型 22 両に FL-17D を10〜15 登点登し，京浜束北線に運転されこれらの 照度分布す詳細に测定され，本誌に(1)発萃された。

以上の点登方式は 强制起動でないのと, 起動リレー り棈造と保守の研究不足，転極操作がスイッチでできな い. 且つ溃光放電登自体が改良の道程中で女って 期待 乙た程の成果が得られず，その後中止され 白慜電球に

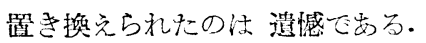

これらの苦い経験によって，FL-20 犆流 $100 \mathrm{~V} て 6$ は dark end effect 多大きく, 且つ起動も困難のた め不向きであり，FL-17 はその現象が医とんどない が，起動方式，リレー等の改良が強く要望された。

d. 昭和 25 年 阪神霍鉄会社が FL-17 の陰極に格 子を入れたもの5登と $40 \mathrm{~W}$ 電球を 3 登㨁列にした 2 回 路を 直流 $600 \mathrm{~V}$ の電車䠌電压により 㨁列点登方式を 採用したと後 FL-20にも同様の力式を採用し， 現在 FLー17，FL一20によって照明され忋電車が 55 両 以上政んでいる(2).

e. 昭和 26 年暮川崎市電の 1 闭に FSL-30W (ス リムライン） 2 登を直流 $600 \mathrm{~V}$ で並直列に点登する新 方式が採用された。䖝光放電登数注片側 5 登宛計 10 登, 読畫面上方の天井に取り付けられた(3).

直流点登方式法 $100 \mathrm{~V}$ 回路に泣 FL-17,600V 回路 には格子入り FL-17，FL-20 の直列 又は FSL-30 の 2 登直列が 現在使われているが，直流点登住直列バ ラストの電力損失注避计難いが，この電力損失をより 小さく寸ること又は 有効几転用する等の苦心が払われ ている.この直流式は 変流装置がないから 低廉に器具

\footnotetext{
* 小糸製作所技淮部 ** 東京都電気研究所
}

はできるが，起動装置の複雑，転極装置等が必要である ため保守上に種々難点が残されている.

\section{（2）交流による点燈}

\section{A. 客 車}

a. 昭和 22 年 7 月 国鉄 2 等車に FL-20D を 客室 に8登, FL-10D を両ステップ および 洗面所に各 1 登 （計 3 登）在点登し，新宿一上諏訪間で試験したのが， 客車に篮光放電登が点登された最初と思われる(4)。点 登用電源は $24 \mathrm{~V}$ 列車蓄電池で $24 \mathrm{~V}$ 一交流 $105 \mathrm{~V}-100$ のー315VAのインバータを運転した。点登回路はグロ 一スイッチ式で各登具にそれぞれ力皐改善用コンデン サを入れて 90\% 以上に保った。

b. 昭和 23 年度 国鉄 1 等寝台車（マイネ 40 型） 21 両に FL-20D × 15 登，FL-10D × 12 登点登した， 当初の電源㤌 1000 であったが，その後 墑用周波数で ないと，種々不便を生じをので55めに改められ，イン バータは新設讘により，登具はバラストチョーク，コン デンサの改修によって 現在好成績で点登されている. インバータは $24 \mathrm{~V}$ 一交流 $105 \mathrm{~V}-55$ 一-315VA 3 台 (内1台予供) である.

c. 昭和 24 年 11 月シャ么国向輸出 2 等車 60 雨に $\mathrm{FL}-20 \mathrm{D} \times 8$ 登, $\mathrm{FL}-10 \mathrm{D} \times 3$ 登, 点登電源江 $24 \mathrm{~V}$ 交流 $105 \mathrm{~V}-55 \diamond-315 \mathrm{VA}$ のインバータで点登し た.

d. 昭和 25 年シャ么国向第 2 次輸出車 25 両に前 記と同様の点燈方式を採用した。

e. 昭和 27 年度 国鉄特別 2 等車（スロ） 20 両にFL - $20 \times 12$ 燈, FL-10 28 登を $24 \mathrm{~V}$ 一交流 $100 \mathrm{~V}-55$ ○ー420V A のインパータ 2 台で点登した。

以上の点登回路标いづれも電源が蓄電池で, 且づ充 電用発電機の速度一電王特性がよいため, その端子電圧の 変化が小さい，従ってインバータの交流側の電王，周波 数とも変動が少ないので，グロースイッチ式の点登回路 を採用し，回路力率を約 95\% に保って满足な結果を得 ている.

\section{B. 電 車}

a. 昭和 25 年 近畿日本鉄道 名古屋一中川間の口マ ンスカー 1 両に直流 $100 \mathrm{~V}$ 一交流 $105 \mathrm{~V}-55 \diamond-500 \mathrm{VA}$ 
インバータで FL-20D x 16 燈を 4 登用スタビラで点 燈した，その後 直流式 又は，交流式によって，大阪一 名古屋間の特急電車 ( 5 両編成) の全部に螢光燈照明を 施してある。

b. 昭和 26 年春 東武電車日光線の ロマンスカー 6 両に FL-20を 1 両に 36 燈点登した. 電源注特殊電動 発電機によって, 交流 110V-120هを発生し，定電圧， 定周波数を発生する方法を講じてあって, 点燈回路は直 列共振式である(5).

c. 昭和 27 年春 東京都電に FL- $20 \times 12$ 登付き 1 両, FL- $40 \times 8$ 燈付き 1 両に溃光燈照明を実施した。点 登回路法 東京都電気研究所発明の, 点登管不要高力率 点登方式（都電研ブリッジ型）のバラストを採用しれ。 このバラストは1個て FL- $20 \times 2$ 燈, FL-40×1 登 点登可能である.

点燈電源注 前者注渎 $550 \mathrm{~V}$ 一交流 $105 \mathrm{~V}-550-$ $500 \mathrm{VA}$ インバータ，後者活 $800 \mathrm{VA}$ インバータで，い づれも前照登, 尾燈, 方向幕登等の電球が並列に点登 されている。

d. 昭和 27 年夏 山陽電鉄 2 両に FL-20×14 燈 ( 1 两当り）を都電研式バラストで点登した。電源は直流 $100 \mathrm{~V}$ 一交流 $105 \mathrm{~V}$-60هー800VA インバータでもる.

e. 昭和 27 年夏 東京急行玉川線 5 兩に FL-40 1

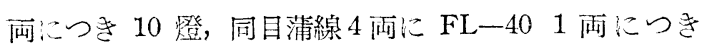
20 燈点登した。前者法 $500 \mathrm{VA}$, 後者法 $800 \mathrm{VA}$ イン バータて，䀦流側 $600 \mathrm{~V}$ で点る. 点登方式注都電研型 バラストを採用した。

\section{C. バ ス}

バスに慗光登点点したの澄，いつごらからか法 余 り明らかでないが，大都市上り地方の交通会社が 先きに 奏施したようである・富山地力铁道会社のバスが 昭和 25 年の春ごろ 4 〜 台に取り付汁を.

電源结 $6 \mathrm{~V}, 12 \mathrm{~V}, 24 \mathrm{~V}$ のいつれかか蓄電池を持。 ていたが，篮光登を点登するに法交流に直さればなら ない. 大型バス法もっぱらディーゼル車で，蓄電池は $24 \mathrm{~V}$ であるから，インバータを運転しているものが多 い.コンドル号のバスに FL- $20 \times 8$ 燈を点燈, 燈具は プラスチックの浅いグローブ付で，点蹬回路注瞬時起動 のようである。

\section{2. 点燈方式}

(1) 直流点燈方式 直流沙る点燈法 現在 100 $\mathrm{V}, 600 \mathrm{~V}, 1,500 \mathrm{~V}$ の 3 種の電生が考元られるが，些用 化されているもの法 $100 \mathrm{~V}$ と $600 \mathrm{~V}$ である. 1,500V はスリム，冷陰極型の起動に溶易であるが，燈具，附 属器具が保安上危惧があるので, 実施されていない。
かって 国電に採用した (東芝式) 直流 $100 \mathrm{~V} に \mathrm{FL}$ -17 を並列に点登する方式，格子入りの FL-17 又は FL-20 直流 $600 \mathrm{~V}$ 回路に直列点燈, FSL-30, 2 燈 を $600 \mathrm{~V}$ 回路に直列点登した例は既に述べたが，直流 点燈方式については，原田常雄氏が 本誌に述べてめる から省略する。

（27 交流点燈方式 交流点燈汁直流式と異な り，電圧のほかに周波数に上る影響が大きく，又，力率 の補償む100\% 近くにしなければならない、電車線電圧 は 定格の 50〜60\% 位まで低下することもあるので， 炇光登の点登用電源を発生させる電動発電機 又注 イン バータの設計に苦心するところである・且つ電源関係の 機器む燈具む堅牢で軽いことが強く要望されている.

A.グロースイッチ式先に述べたように1等 寝台車 (マイネ 40 型)，シャ么国向輸出車，今年度の特 別2等車等に採用して㣻るが，電源電生注 添とんど 23 〜25 V 間に岕るから，交流側む90 V 以下になること

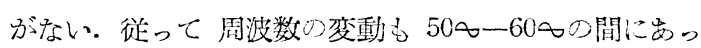

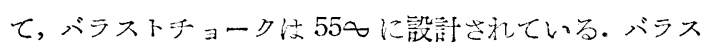
卜は密閉されて使用されるから，その直流抵抗を少なく し，陰極が点登したままになっても，㜔損の恐れのない ようになっている，点登回路法 一般の栖準回路て FL20 に法 $8 \mu \mathrm{F}, \mathrm{FL}-10$ に $4 \mu \mathrm{F}$ が電源端子に並列に 接綕されて才率范 90〜95\% に保っている.

B. 共振回路方式(5.6) 交流点燈力式注定電 生，定周波数の電源が必要条件でるが，霍車線電生の ように，季節，1日中の時間 又注路線の区閒によって 大幅に变る.この電源て運転される電動発電機 又注、イ ンバータの卒流側仗当然変化し，乙のま李で法点登用 雪源にならないが 東京芝浦雪気会社が，特秼の安定装 置を施した電動発電機(卒流側 $110 \mathrm{~V}-120 \diamond$ ) 設計し, 前記 東武線のロマンスカーに採用した。关の点登回路の 結線注第1图に示寸よ万に $L_{1}$ 名篮光放電登に直列に，

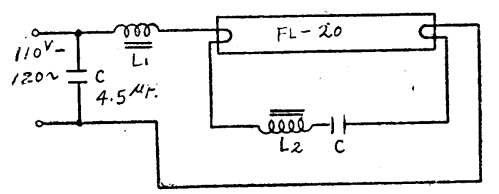

第 1 圆東芝式共振回路方式

$L_{2} ， C$ が除極を通じて並列になっている. 点燈特性法 瞬時点啙で電圧 周波数に対してかなりの許容範囲があ り，電源端子に $4.5 \mu \mathrm{F}$ を接続すると力率 $90 \%$ になる.

C. 点燈管不要高力率点燈回路 (都霞研ブリッシ 型）普通の共振式による点燈注 周波数の高い程 好結 果を得るが,この方式汢 商用周波数でも充分满足な成果 
を得ている. もらろん 周波数の高くなるに従つて 部品 は小型になり，ちらつきは減少与る。

この点燈回路壮第 2 図の略線図

に示すよらに，インピーダンスを ブリッジに接続し，各枝路のイン ピーダンスを $Z_{L^{\prime}}, Z_{\sigma^{\prime}}, Z_{L^{\prime \prime}}$, $Z_{\text {O" }}$ および電源側にインピーダ ンスZを挿入したもので, $Z_{L}^{\prime}$, $Z_{\sigma^{\prime}}$ 又は $Z_{L}{ }^{\prime \prime}, Z_{O^{\prime \prime}}$ の間に篮光 放電燈の各電極を接続してある. 起動のときは 電源電纴 $E$ を端 子に加えると $Z_{L^{\prime}}, Z_{O^{\prime}}$ と $Z$ と，

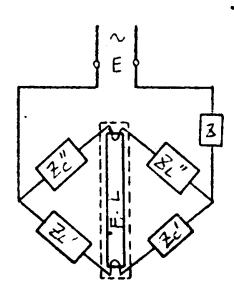

第 2 図 高力率点登回路都 電破ブリッジ型
$Z_{\mathbf{L}}{ }^{\prime \prime}, Z_{O^{\prime \prime}}, Z$ の 2 回路が共振し，両電極間に高い電珐 が加えられ，それと同時に電極を熱し点燈する。

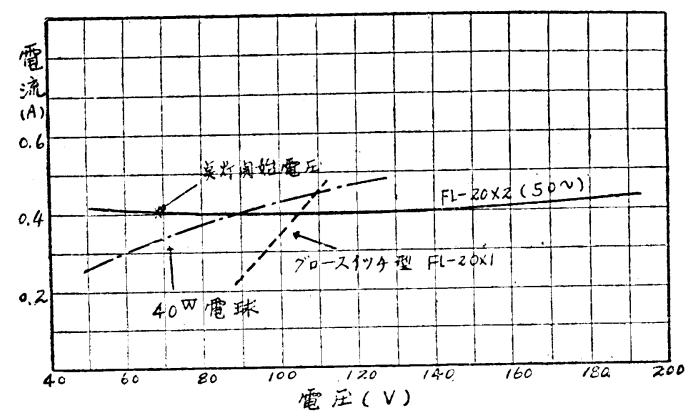

$(\mathrm{FL}-20 \times 2$ 燈 $)$

第 3 図都電研ブリッジ型点燈特性

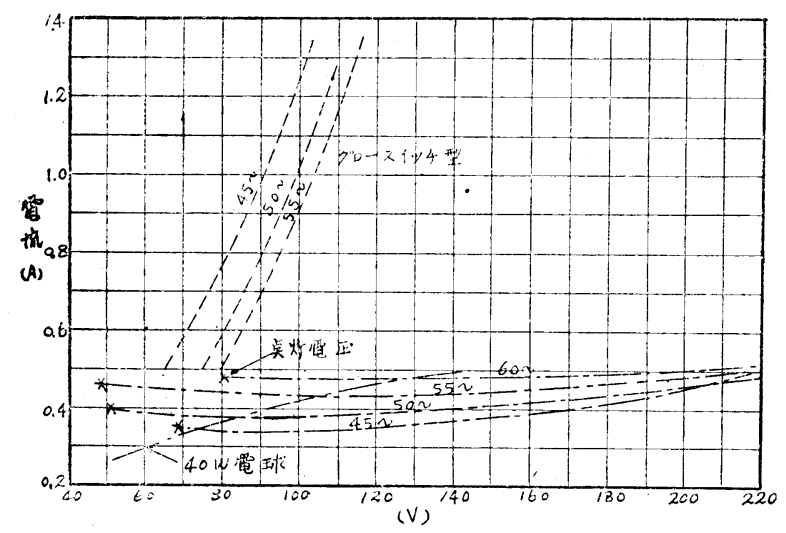

$(\mathrm{FL}-40 \times 1$ 登 $55 \infty$ 用)

第 4 図 都電研ブリッジ型点燈特性

この点登回路の特徵注下記のようで，第3図仗 FL - $20 \times 2$ 登第 4 図は FL-40×1 登用の電生電流 およ び 周波数に刘する特性を示している. 第5 図法 各電生 に対与る力率を表わしている。

特 徴

(a) 点燈管を使用しない.

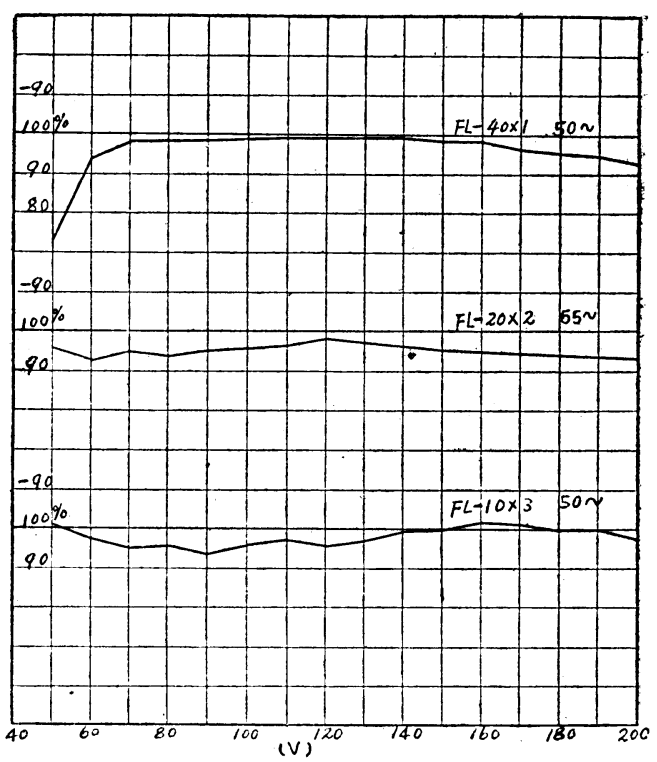

第 5 図 都電研ブリッ沙型点登回路力率特性

(b) 電源電圧 $100 \mathrm{~V}$ 回路に变圧器を使用せず， $40 \mathrm{~W}$, 100W 管等 使用可能で方る.

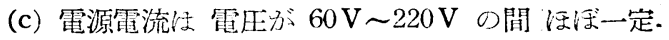

(d) 力率江電源電压 $60 \mathrm{~V} \sim 220 \mathrm{~V}$ の間 約 $100 \%$

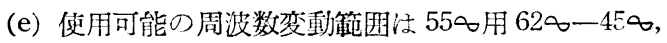
$100 \diamond$ 用 $120 \diamond-60 \diamond ， 500 \diamond$ 用 $600 \diamond-400 \diamond$.

(f) 特殊の容器を使用せ广゙彷来の燈具内に納末る。

（g）低温 $0^{\circ} \mathrm{C}$ 位まででとのまま使用可能 で女る。それ以下 $-20^{\circ} \mathrm{C}$ 位で恃，電压を 少し高くすればな招安定である。

(h) $40 \mathrm{~W}, 100 \mathrm{~W}$ 管等を 2 倍の出力 $80 \mathrm{~W}, 200 \mathrm{~W}$ 管として使用でさる。

この点蹬回路の使用権を小系製作所が得て呏

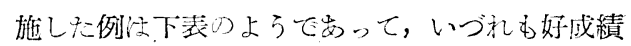
を得ている。

\begin{tabular}{|c|c|c|c|c|c|}
\hline \multirow{2}{*}{ 採用:先 } & \multirow{2}{*}{$\frac{\text { 登具数 }}{(1 \text { 耐当 } v)}$} & \multicolumn{2}{|c|}{ 䖝光放電殈 } & \multirow{2}{*}{$\begin{array}{c}\text { インバー } \\
\text { 久の容量 } \\
{[\mathrm{VA}]}\end{array}$} & \multirow{2}{*}{ 事西数 } \\
\hline & & $\begin{array}{l}\text { 沼留電 } \\
\text { 力 }[W]\end{array}$ & 本 & & \\
\hline 柰京都烈 & 6 & 20 & 12 & 500 & 1 \\
\hline 東京都電 & 4 & 40 & 8 & 800 & 1 \\
\hline 東急玉川線 & 5 & 40 & 10 & 500 & 5 \\
\hline 本急目蒲線 & 10 & 40 & 20 & 800 & 4 \\
\hline 叫陽霍鉄 & 7 & 20 & 14 & 800 & 2 \\
\hline
\end{tabular}

(詰) 1. 東京都電 2 画は前照登, 方向募燈, 尾燈 などの電球がインバータからとっている。

2.山陽電鉄は 1 台のインバータで 2 兩分を受持っ ている・ 


\section{3. 照明器具}

登光登照明用照明器具は，一般照明用照明器具の具備 ナる条件と同様にとの条件が要求されるが,特に下記 の点を注意して設計しなければならない。

(a) 振動に充分酎える構造でること.

(b) 軽量て堅牢であること.

(c) 取付関係は 充分過ぎる程入合ごあること。

(d) ソケットは 耐振構造であること.

車両俚幅 $2.8 \mathrm{~m}$ 以下, 長さ $20 \mathrm{~m}$ 以下の細長い 且 つ 天井の低い室であるら，照明器具む自ら大きさに制 限がある. 螢光放電登は 細長く 且つ 発熱も少ないの て，器具はかなり浅い、型にてきるから，車両の照明用光 源として最適である。

䖝光放電登の大きさは 客車用には現在 $20 \mathrm{~W}, 10 \mathrm{~W}$ 2 種に限られているが, 電車は 17 W， 20 W， 40 W，ス リムライン $30 \mathrm{~W}$ が使用されている.

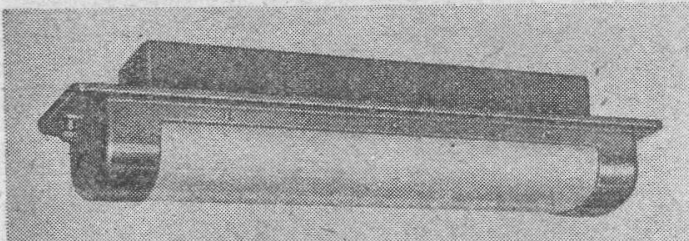

第 6 図特別 と等車用 $\mathrm{FL}$-20 (小系製)

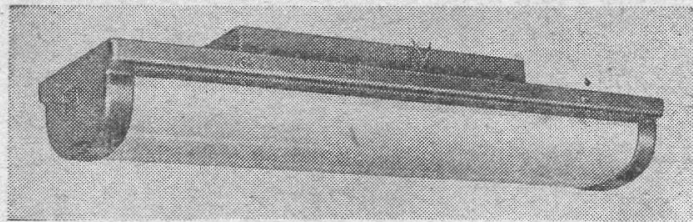

第 7困 特別 2 等車用 FL-10 (小糸製)

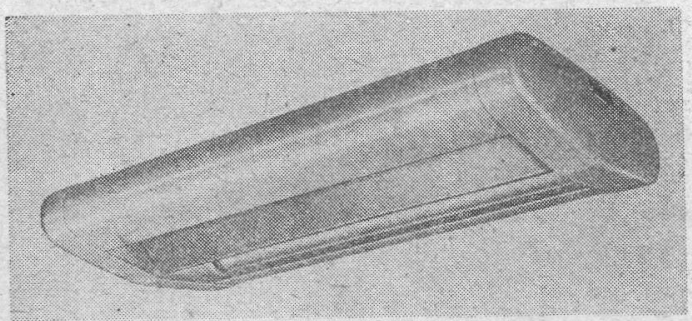

第 8 困 小糸製登具 (FL-20×2燈用)

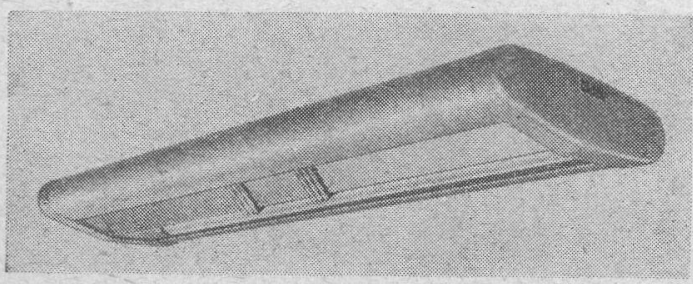

第9図 小糸製燈具 (FL-40×2燈用)
器具の型式は 裸ランプ,グロープ 付抽よ゙ルーパ付 厄大きさ忙 $\mathrm{FL}-20 \times 4$ 燈用，FL- $40 \times 2$ 燈用まで使 用されている.第 6 図，第 7 図は特別 2 等車用，第 8 図 は20W × 2 短用，第 9 図は $40 \mathrm{~W} \times 2$ 燈用で，反射板は アルミニウムの電解研磨，グローブは乳色プラスチック である。

\section{4. 実施例}

螢光燈照明を実施した二，三の例をあげると

(1) 客 車 (特別 2 等車)

\begin{tabular}{r|r|r|r|r}
\hline 器 具 & 天井 燈 & 座席 燈 & その他 & 計 \\
\hline 放電登 & & & \\
\hline F L - 20 & 12 & - & - & 12 \\
F L -10 & - & 24 & 4 & 28 \\
\hline
\end{tabular}

照度 座席の読書面 $110 \mathrm{~lx}$ （全燈点燈） 通路 (休面) $501 \mathrm{x}$ (全燈点燈)

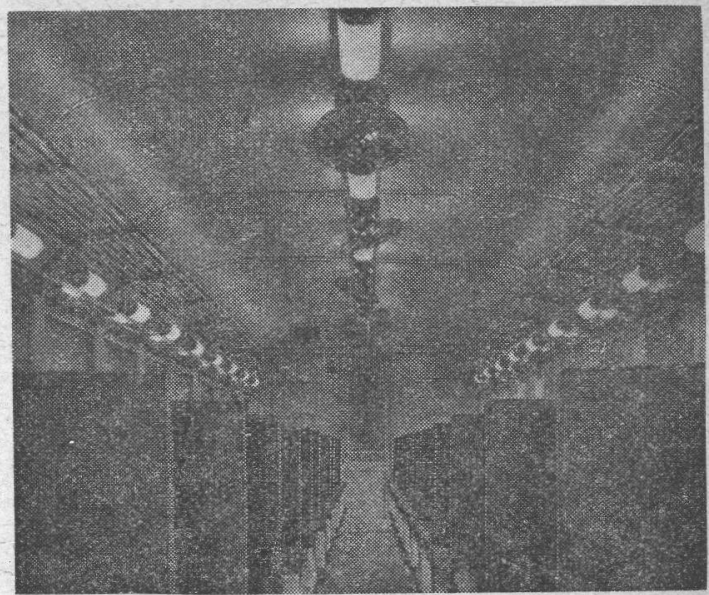

第 10 兇 特別 $\angle$ 等車 $(\mathrm{FL}-20 \times 12$ 燈, FL- $10 \times 24$ 燈)

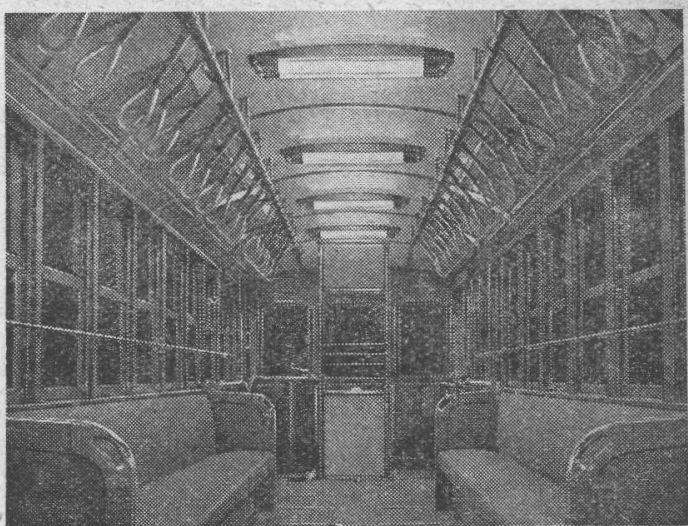

第 11 汹東京都電 (62型) 螢光燈照明

(2) 電 車 


\begin{tabular}{|c|c|c|c|c|c|c|}
\hline & 燈 & 隥具数 & $\begin{array}{c}\text { 照度読面書 } \\
\text { [lx] }\end{array}$ & 点䗳方式 & $\begin{array}{c}\text { 交 流 } \text { 電 源 } \\
{[\mathrm{V}]}\end{array}$ & 周 波 数 \\
\hline 東京都 電 & $\mathrm{FL}-20 \times 2$ 燈用 & 6 & 80 & 都電研型 & $80 \sim 120$ & 55 \\
\hline 東京都電 & $\mathrm{FL}-40 \times 2$ 䗳用 & 4 & 120 & 都電研型 & $80 \sim 120$ & 55 \\
\hline 東急玉川線 & $\mathrm{FL}-40 \times 2$ 短用 & 5 & 130 & 都電研型 & $80 \sim 120$ & 55 \\
\hline 東急目蒲線 & $\mathrm{FL}-40 \times 1$ 登用 & 10 & 120 & 都電研型 & $80 \sim 120$ & 55 \\
\hline 山陽電鉄 & FL $-20 \times 2$ 登用 & 7 & 80 & 都電研型 & $80 \sim 120$ & 55 \\
\hline
\end{tabular}

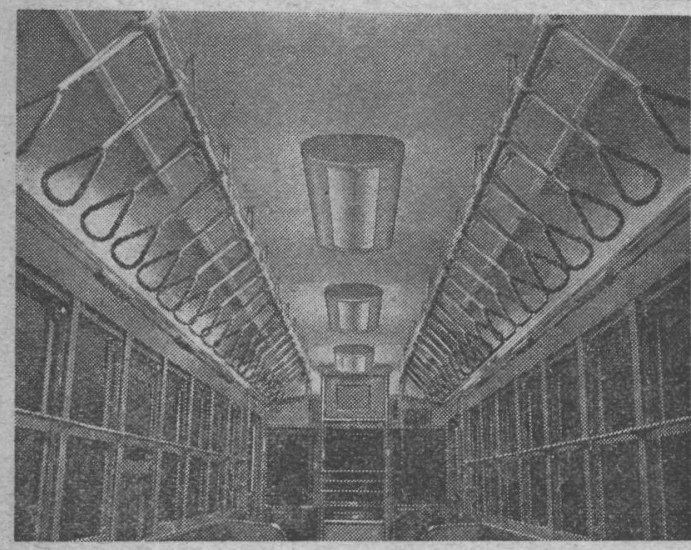

$(\mathrm{FL}-40 \times 2$ 燈 $) \times 4$

第 12 図 東京都電 (32型) 螢光登照明

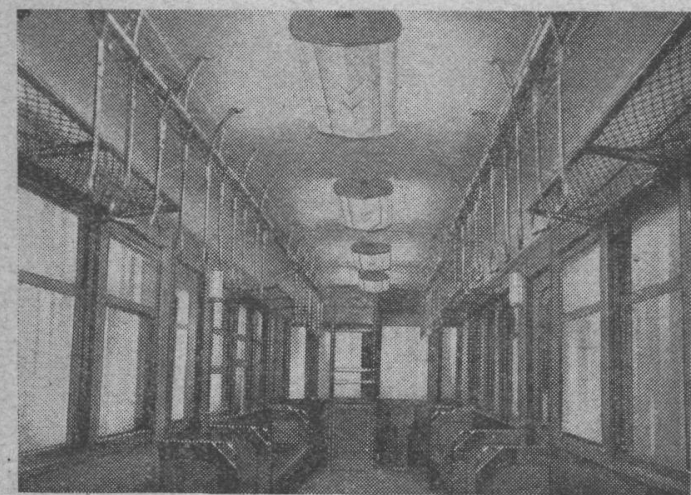

第 13 図 東京急行玉川線 $(F \mathrm{~L}-40 \times 2$ 燈 $) \times 5$

\section{5. むすび}

事両は 保安運転が最重要条件でるが, 各電鉄会社が speed up，防振，防音および照度の改善に力を入れてい る.

溃光燈照明も溃光放電燈の改良と相まって，そのよさ が分り，実施車両数もますます增加の一途を辿っている が, 直流式 交流式とも標淮点燈回路方式といらべきもの が1またと決まるところまでいっていない，要するに 低廉 它安定な点燈方式，且つ保守に手数の掛らないす!のが 要望されることは当然である.

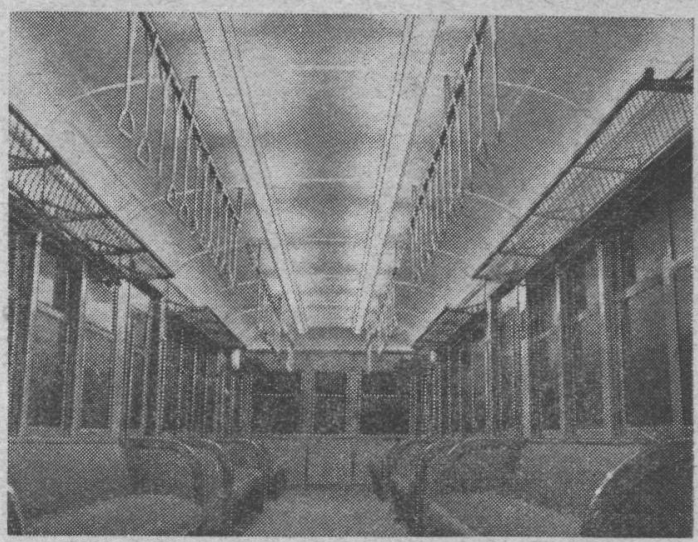

$(\mathrm{FL}-40 \times 1$ 燈 $) \times 20$

第 14 図 東京急行目蒲線電車螢光燈照明

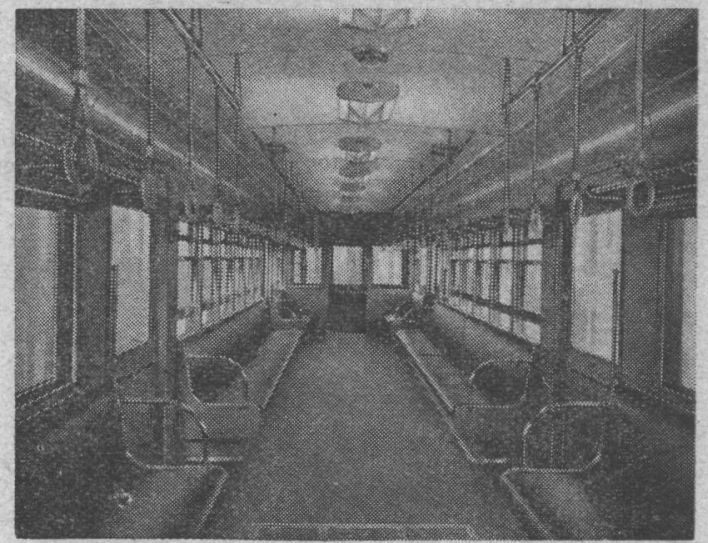

第 15 図山陽電鉄電車内照明

交献

（1）照学誌 33,5 (昭 24) p. 134

（2）照学誌 34,10 (昭 25) p. 14

(3) 26回連合大会論文集 (27年春) 7-14

(4) 照明月報 $(22-89)$ p. 2

(5) 照学誌 35,5 (昭 26) p.178

(6) 機械学会講習会 (46回27年5月) p. 67 